QUARTERLY

\title{
Modulation of human deoxycytidine kinase activity as a response to cellular stress induced by $\mathrm{NaF}^{\star \star}$
}

\author{
Zsolt Csapó, Maria Sasvári-Székely, Tatjana Spasokoukotskaja and Mária Staub ${ }^{\bowtie}$ \\ Institute of Medical Chemistry, Molecular Biology and Pathobiochemistry, \\ Semmelweis University, Budapest, Hungary
}

Received: 12 October, 1999; revised: 7 February, 2000; accepted: 31 January, 2001

Key words: deoxycytidine kinase, $\mathrm{NaF}$, lymphocytes, tonsil

\begin{abstract}
Deoxycytidine kinase (dCK) is one of the key enzymes of deoxynucleoside salvage supplying resting lymphocytes with DNA precursors for synthesis and repair. The level of dCK activity is especially important in chemotherapy with the use of deoxynucleoside analogues like arabinosyl cytosine (Citarabid, ara-C), or 2-chloro-deoxyadenosine (Cladribine, CdA). Previous results showed that Cladribine treatment of human lymphocytes increased several fold the activity of $\mathrm{dCK}$ without increasing the amount of dCK protein itself (Sasvári-Székely, et al., 1998, Biochem. Pharmacol. 56, 1175), and a possible post-translational modification was suggested. This theory was further investigated using $\mathrm{NaF}$ as an inhibitor of protein phosphatases. It was shown that $\mathrm{NaF}$ treatment of cells elevated dCK activity while inhibiting DNA synthesis. The possible mechanism of dCK activation/inactivation induced by exposure of cell cultures to different agents is discussed.
\end{abstract}

Deoxycytidine kinase (dCK, EC 2.7.1.74) is a key enzyme supplying precursors for DNA synthesis in lymphocytes [1], therefore its activity affects cell survival, as well as cell death. dCK has an interestingly broad substrate specificity [2]. This enzyme is able to phosphorylate three of the four deoxynucleosides, moreover, the fourth deoxynucleotide, dTMP, can also be formed from
dCMP. Consequently, dCK can supply all the precursors needed for DNA synthesis in $G_{0} / G_{1}$ phase lymphocytes. Beside its high expression in lymphoid tissues [3, 4] significant dCK activity was found in solid tumours [5]. As the enzyme activates a large variety of deoxynucleoside analogues used in anticancer and antiviral therapy [6], its activity has a high relevance to the thera-

\footnotetext{
$\bar{\star}$ Presented at the 7th Symposium of the European Society for the Study of Purine \& Pyrimidine Metabolism in Man, 1999, Gdańsk, Poland.

This work was carried out within the framework of the EU Biomedical and Health projects BMH 4-CT96-0479 and funded by the Hungarian grants ETT T11 061/98 and OTKA T022608.

${ }^{\bowtie}$ Corresponding author: Prof. Mária Staub, M.D., Ph.D., Department of Medical Chemistry, Molecular Biology and Pathobiochemistry, Semmelweis University H-1444 Budapest-8, POB 260, Hungary; tel.: (361) 2662755 ext. 4003 ; fax: (361) 266 2615; e-mail: staub@puskin.sote.hu
}

Abbreviations: ara-C, arabinosylfuranosylcytosine; dCK, deoxycytidine kinase; dTK, deoxythymidine kinase; CdA (Cladribine), 2-chloro-deoxyadenosine. 
peutic effectiveness of treatment of different types of leukemia [7, 8]. Moreover, development of resistance during chemotherapy can often be the result of inactivation of dCK. For these reasons, processes leading to activation/inactivation of dCK have a high clinical relevance. For example, the effectiveness of 2-chloro-deoxyadenosine (CdA, Cladribine) administration was shown to correlate with the in vitro phosphorylation capacity of peripheral blood mononuclear cells (i.e. dCK activity) from leukemic patients [9]. Combination therapy with ara-C and Cladribine was applied successfully probably due to increased intracellular phosphorylation of ara-C [10], which suggested elevation of cellular dCK activity during the therapy. Etoposide was also shown to increase dCK activity in L 1210 murine leukemic cells [11].

Interestingly enough, very little is known about the regulation of expression and activity of this key enzyme in deoxynucleoside salvage and DNA repair. dCK is known to be under a feedback control by dCTP [6, 12]. Inhibition of several enzymes, such as ribonucleotide reductase [13], dCMP deaminase [14] and adenosine deaminase [15] by intracellular metabolites of chemotherapeutic agents, e.g. Cladribine, might alter the deoxynucleotide pools, thus influencing the activity of dCK. However, measurement of total dCTP pool might be not informative enough, as compartmentation of dCTP pool has been observed in tonsillar lymphocytes [16] and in other cells [17]. Several functions of the separate dCTP pools have been proposed: one serving DNA replication, the other supplying precursors for synthesis of membrane phospholipids and DNA repair $[16,17]$. Deoxycytidine kinase is a constitutive enzyme, mainly expressed in lymphoid and in mononuclear blood cells [1], and localized in the cytoplasm [18]. Previous experiments in our laboratory have shown stimulation of dCK activity after incubation of human lymphocytes with Cladribine without any increase in the protein expression [19]. Other deoxynucleoside analogues were also studied in detail in view of their activating effect on dCK [20]. The main goal of the experiments presented in this paper is to answer the question whether dCK activity can be influenced only by its substrate analogues or whether com- pounds other than deoxynucleotides can also elevate the phosphorylation capacity of dCK.

\section{MATERIALS AND METHODS}

Cells, treatment and labelling. The primary culture of human tonsillar lymphocytes was prepared as previously described [21]. Cells were treated with $\mathrm{NaF}$ in serum-free Eagle's Minimal Essential medium and pulse-labelled either with [methyl- $\left.{ }^{3} \mathrm{H}\right]$ thymidine or with $2^{\prime}$-deoxy $\left[5-{ }^{3} \mathrm{H}\right] \mathrm{cy}-$ tidine $(1.0 \mu \mathrm{Ci} / \mathrm{mL})$ for $20 \mathrm{~min}$. After pulse labelling, the cells were washed and fractionated into nucleotide, liponucleotide and DNA fractions [22].

\section{Purification and assay of dCK and dTK ac-} tivity. Parallel cultures of control and $\mathrm{NaF}$ treated cells were collected by centrifugation, and dCK and dTK activity was measured in crude cell extracts and after partial purification of dCK as previously described [23], with some modifications: Crude cell extracts were prepared in $5 \mathrm{~mL}$ of $50 \mathrm{mM}$ Tris/HCl buffer, $\mathrm{pH} 7.6$, containing 2 $\mathrm{mM}$ dithiothreitol, $21 \%$ glycerol, $0.5 \%$ Nonidet P-40 and $0.5 \mathrm{mM}$ phenylmethylsulfonyl fluoride by homogenization and by repeated freezing-thawing cycles in liquid nitrogen. After centrifugation at $104000 \times \mathrm{g}$ at $4^{\circ} \mathrm{C}$ for an hour, the supernatant (about $20 \mathrm{mg}$ protein in $4 \mathrm{~mL}$ ) was applied onto a DEAE-Sephadex A-25 column, equilibrated with buffer A $(50 \mathrm{mM}$ imidazole buffer, $\mathrm{pH} 7.0$, containing $5 \mathrm{mM} \mathrm{MgCl}_{2}, 4 \mathrm{mM}$ $\beta$-mercaptoethanol, $20 \%$ ethyleneglycol) and eluted with a linear $0-1 \mathrm{M} \mathrm{KCl}$ gradient. For the assay of dCK activity, fractions were reactivated by $20 \mathrm{~min}$ incubation with $50 \mathrm{mM}$ dithiothreitol and $1 \mathrm{mg} / \mathrm{mL}$ bovine serum albumin.

\section{RESULTS AND DISCUSSION}

$\mathrm{NaF}$ was chosen for treatment of lymphocytes as it is easily taken up by the cells, affects probably the nucleotide metabolism, but has no structural similarity to the deoxynucleosides or nucleotides. To investigate the effect of NaF treatment on lymphocytes, the nucleotide, liponucleotide and DNA 
metabolism was followed during $20 \mathrm{~min}$ of pulse labelling of the cells either with $\left[5^{3} \mathrm{H}\right]$ deoxycytidine (Fig. 1A: ${ }^{3} \mathrm{H}-\mathrm{dC}$ ), or with $\left[5^{3}{ }^{3} \mathrm{H}\right]$ thymidine (Fig. 1B: ${ }^{3} \mathrm{H}-\mathrm{dT}$ ). Pulse labelling was applied at indicated periods after the beginning of $\mathrm{NaF}$ treatment, then the incorporation of the label was determined in different components of the cells: in the nucleotide, liponucleotide and in the DNA fractions. Labelling of cells with ${ }^{3} \mathrm{H}$-dC resulted in a significant accumulation of radioactivity in the nucleotide and liponucleotide fractions, in good agreement with our previous results [21]. In the presence of $\mathrm{NaF}$ the level of free nucleotides was increased simultaneously with a decrease in their incorporation into the DNA fraction (Fig. 1A). Labelling with ${ }^{3} \mathrm{H}-\mathrm{dT}$ resulted in a much lower level of free nucleotides and a dramatic decrease in their incorporation into DNA (Fig. 1B). These data suggest an increased rate of ${ }^{3} \mathrm{H}-\mathrm{dC}$ phosphorylation as well as a dramatic inhibition of DNA synthesis by $\mathrm{NaF}$. phocytes with $15 \mathrm{mM} \mathrm{NaF}$ was about twice as high as the initial level. At that time, DNA synthesis was completely inhibited by NaF (Fig. 1B). Control cells were incubated without $\mathrm{NaF}$, and there was no significant change in dCK activity, and only a slight decrease in dTK activity. When $1 \mathrm{~h}$ of incubation at increasing concentrations of $\mathrm{NaF}$ was applied, dCK activation was found to be the highest between 10 and $20 \mathrm{mM} \mathrm{NaF}$ (Fig. 2B). Again, no similar changes were observed in the level of dTK activity. Thus the stimulatory effect of $\mathrm{NaF}$ treatment seems to concern specifically $\mathrm{dCK}$, and has no influence on the activity of another nucleoside salvage enzyme, dTK.

As the modulatory effect of the intracellular $\mathrm{dTTP} / \mathrm{dCTP}$ pool is well known from the work of Plunkett's group [24], the increased enzyme activity could be ascribed to the allosteric activation of the enzyme by a small effector molecule. Generally, allosteric effectors can be separated easily from proteins by column chromatography. Crude

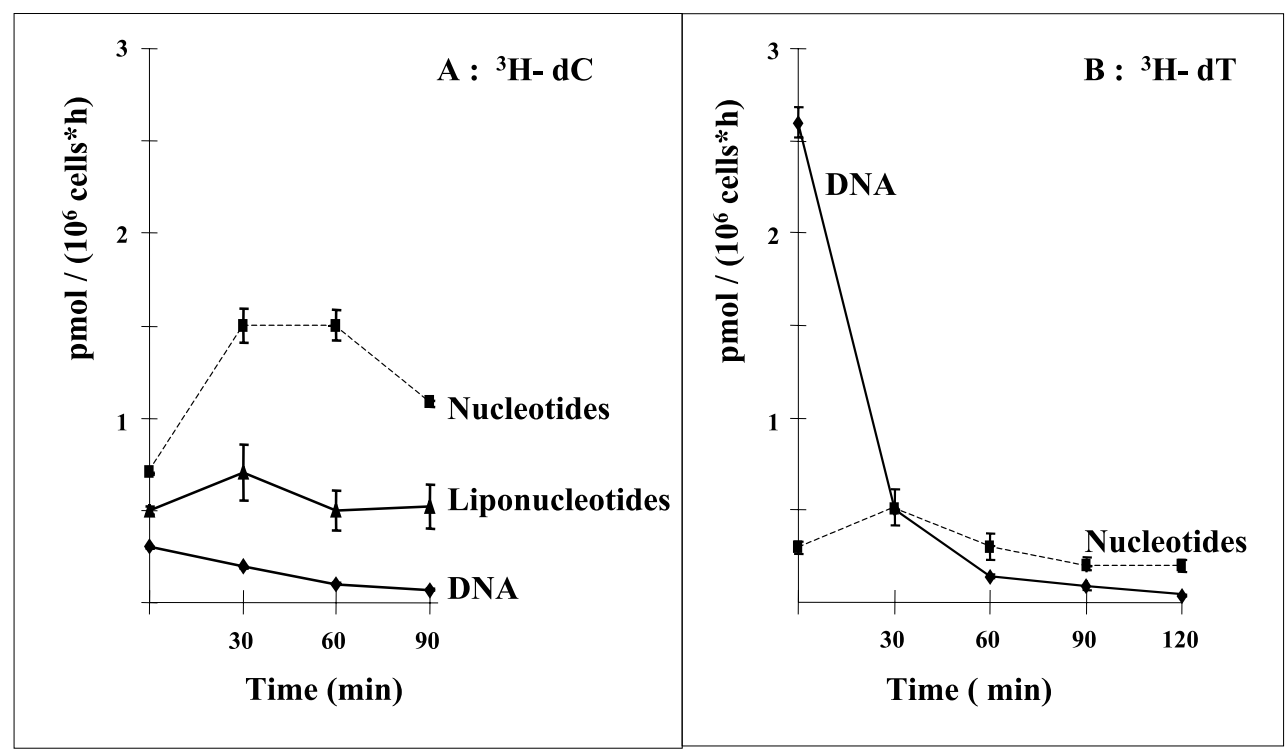

Figure 1. Effect of NaF treatment on the metabolism of $\left[{ }^{3} \mathrm{H}\right] \mathrm{deoxycytidine}(\mathrm{A})$ and $\left[{ }^{\mathbf{3}} \mathrm{H}\right] \mathrm{deoxythymidine}(\mathrm{B})$.

Human lymphocytes in culture were pulse labelled either with $\left[{ }^{3} \mathrm{H}\right]$ deoxycytidine $\left({ }^{3} \mathrm{H}-\mathrm{dC}\right)$ or with $\left[{ }^{3} \mathrm{H}\right]$ thymidine $\left({ }^{3} \mathrm{H}-\mathrm{dT}\right)$ for $20 \mathrm{~min}$ at different time after treatment with $15 \mathrm{mM} \mathrm{NaF}$. By the end of the pulse labelling, cells were chilled on ice, washed and separated into nucleotide ( $\square$, dotted line), liponucleotide $(\bullet$, continuous line) and DNA ( $\bullet$, continuous line) fractions.

Investigation of the crude extracts of the cells, treated with $\mathrm{NaF}$ as described above, revealed the activation of $\mathrm{dCK}$ by $\mathrm{NaF}$ (Fig. 2A). The maximum of dCK activity after $1 \mathrm{~h}$ incubation of lym- extract was applied on DEAE-Sephadex column to test the hypothesis that the loss of the activator molecule during the purification process leads to the loss of dCK activation. After purification it 


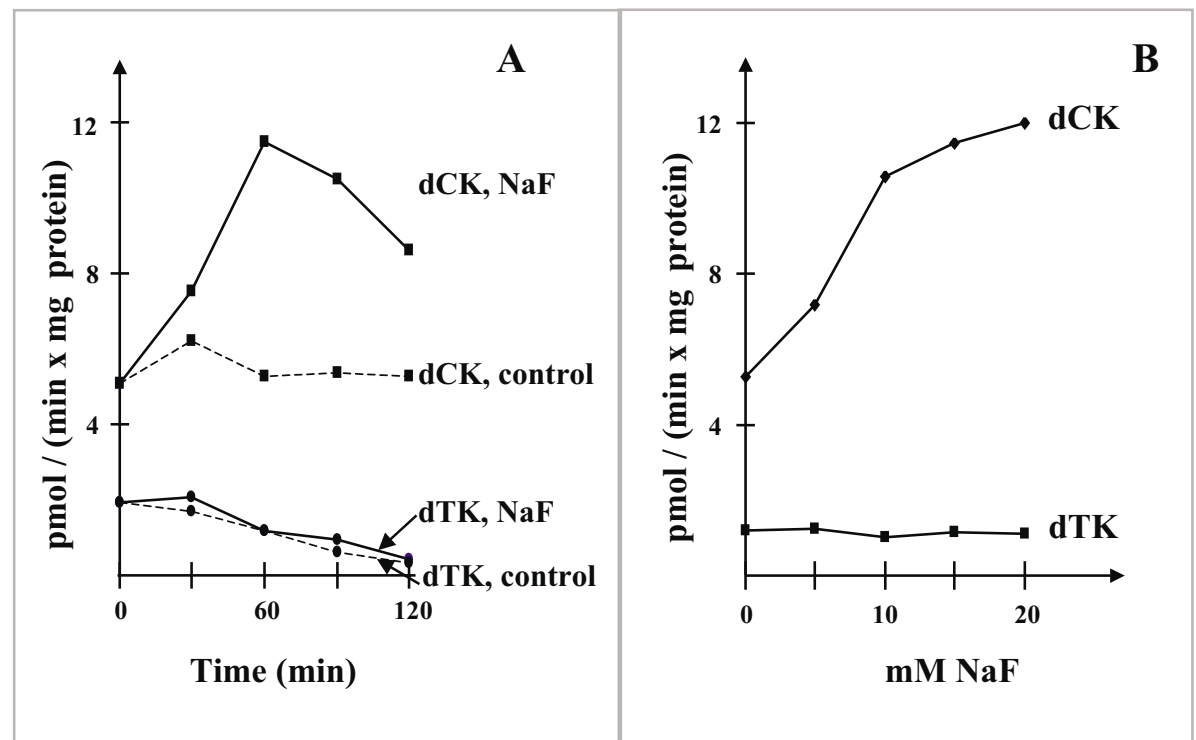

Figure 2. Activation of deoxycytidine kinase of human lymphocytes by NaF treatment.

A: Cells were incubated either in the absence (dotted lines) or in the presence (continuous lines) of $15 \mathrm{mM} \mathrm{NaF}$ for different time periods. Then dCK $(\bullet)$ and dTK $(\bullet)$ enzyme activities were measured in crude cell extracts. B: Cells were incubated in the presence of different concentrations of $\mathrm{NaF}$ for $1 \mathrm{~h}$. Crude cell extracts were prepared after the treatment and the maximum velocity of dCK $(\diamond)$ and $\operatorname{dTK}(\boldsymbol{\square})$ were measured under optimal conditions and at substrate saturation.

was still possible to demonstrate the enhanced dCK activity (Fig. 3) which rules out the role of loosely bound effector molecules. Our preliminary experiments based on immunostaining of the peak fractions showed that the higher enzyme activity can be observed at the same dCK protein content, suggesting post-translational activation as a possible mechanism for dCK activation, in agreement with our previous results [19]. The possible post-translational modifications of enzyme activity are numerous. As $\mathrm{NaF}$ is a known inhibitor of protein phosphatases [25], one possible explanation is the activation of $\mathrm{dCK}$ by enzyme phosphorylation. These data are consistent with the results of Wang \& Kucera [26] who found that the activation of dCK was increased by in vitro protein kinase $\mathrm{C}$ treatment. However, the exact mechanism of $\mathrm{dCK}$ activation in vivo needs further investigation.

In conclusion, the results presented here show the activation of dCK by $\mathrm{NaF}$ treatment of human lymphocytes. NaF treatment, of course, is not of a direct clinical importance. However, these results might give some insight into the mechanism of dCK activation through either a disturbance of

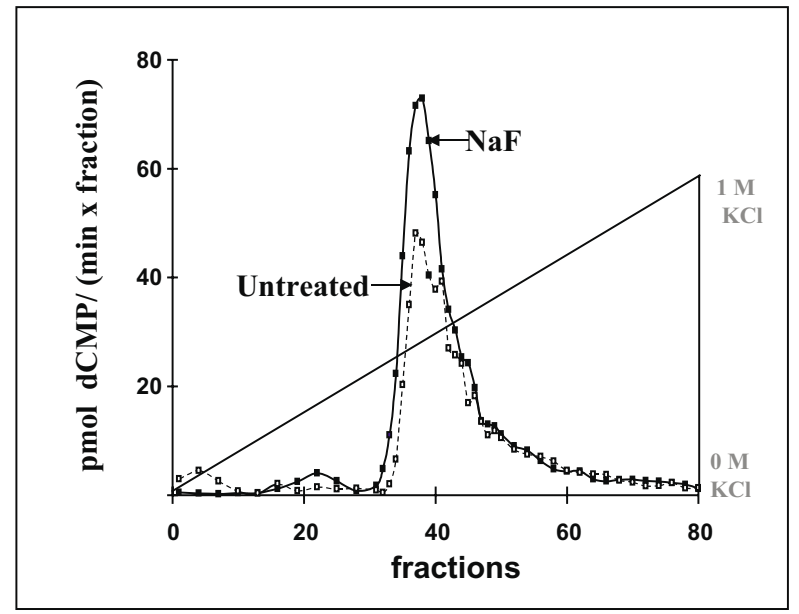

Figure 3. Deoxycytidine kinase activity in purified extracts from $\mathrm{NaF}$ treated and control cells.

Human lymphocytes were incubated in the presence ( $\square$ ) or absence ( $\square$, dotted line) of $15 \mathrm{mM} \mathrm{NaF}$ for $2 \mathrm{~h}$. Then crude extracts were subjected to purification by ultracentrifugation and DEAE-Sephadex chromatography. dCK was eluted by $0-1 \mathrm{M} \mathrm{KCl}$ gradient and the activity was measured in each fraction.

the nucleotide pools or inhibition of the cellular protein phosphatases. 


\section{R E F E R E N C E S}

1. Arner, E.S. \& Eriksson, S. (1995) Mammalian deoxyribonucleoside kinases. Pharmacol. Ther. 67, $155-186$.

2. Datta, N.S., Shewach, D.S., Hurley, M.C., Mitchell, B.S. \& Fox, I.H. (1989) Human T-lymphoblast deoxycytidine kinase: Purification and properties. Biochemistry 28, 114-123.

3. Plunkett, W. \& Saunders, P.P. (1991) Metabolism and action of purine nucleoside analogues. Pharmacol. Ther. 49, 239-268.

4. Kawasaki, H., Carrera, P.J., Piro, L.D., Saren, A., Kipps, T.J. \& Carson, D.J. (1993) Relationship of deoxycytidine kinase and cytoplasmic 5 '-nucleotidase to the chemotherapeutic efficacy of 2-chlorodeoxyadenosine. Blood 81, 597-601.

5. Ruiz van Haperen, V.W.T., Veerman, G., Eriksson, S., Boven, E., Stegmann, A.P., Hermsen, M., Vermorken, J.B., Pinedo, H.M. \& Peters, G.J. (1994) Development and molecular characterization of a 2 ',2'-difluorodeoxycytidine-resistant variant of the human ovarian carcinoma cell line A2780. Cancer Res. 54, 4138-4143.

6. Eriksson, S., Kierdaszuk, B., Munch-Petersen, B., Öberg, B. \& Johansson, N.G. (1991) Comparison of substrate specificities of human thymidine kinase 1 and 2 and deoxycytidine kinase toward antiviral and cytostatic nucleoside analogues. Biochem. Biophys. Res. Commun. 176, 586-592.

7. Beutler, E. (1992) Cladribine (2-chlorodeoxyadenosine) Lancet 340, 952.

8. Juliusson, G., Elmhorn-Rosenborg, A. \& Liliemark, J. (1992) Response to 2-chlorodeoxyadenosine in patients with B-cell chronic lymphocytic leukemia resistant to fludarabine. N. Engl. J. Med. 327, 1056-1061.

9. Eriksson S., Arner, E., Spasokoukotskaja, T., Wang, L., Karlsson, A., Brosjö, O., Gunven, P., Julusson, G. \& Liliemark, J. (1994) Prospectives and levels of deoxynucleoside kinases in normal and tumor cells: Implications for chemotherapy. Adv. Enzyme Regul. 34, 13-45.

10. Gandhi, V., Estey, E., Keating, M.J., Chucrallah, A. \& Plunkett, W. (1996) Chlorodeoxyadenosine and arabinosylcytosine in patients with acute myelogenous leukemia: Pharmacokinetic, pharmaco- dynamic, and molecular interactions. Blood 87, 256.

11. Ooi, K., Ohkube, T., Higashigawa, M., Kawasaki, H. \& Sakurai, M. (1996) Increased deoxycytidine kinase activity by etoposide in L1210 murine leucemic cells. Biol. Pharm. Bull. 19, 1382.

12. Datta, N.S., Shewach, D.S., Mitchell, B.S. \& Fox, I.H. (1989) Kinetic properties and inhibition of human T lymphoblast deoxycytidine kinase. J. Biol. Chem. 264, 9359-9364.

13. Heinemann, V., Xu, Y.Z., Chubb, S., Sen, A., Hertel, L.W., Grindey, G.B. \& Plunkett, W. (1990) Inhibition of ribonucleotide reductase in CCRF-CEM cells by 2 '2'-difluorodeoxycytidine. Mol. Pharmacol. 38, 567-572.

14. Sasvári-Székely, M., Piróth, Zs., Kazimierczuk, Z. \& Staub, M. (1994) A novel effect of the new antileukemic drug, 2-chloro-2'-deoxyadenosine, in human lymphocytes. Biochem. Biophys. Res. Commun. 203, 1378-1384.

15. Fabianowska-Majewska, K., Tybor, K., Duley, J. \& Simmonds, A. (1995) The influence of 2-chloro-2'-deoxyadenosine on metabolism of deoxyadenosine in human primary CNS lymphoma. Biochem.-Pharmacol. 50, 1379-1383.

16. Spasokoukotskaja, T., Sasvári-Székely, M., Taljanidisz, J. \& Staub, M. (1992) Compartmentation of dCTP pools disappears after hydroxyurea or araC treatment in lympocytes. FEBS Lett. 297, 151-154.

17. Xu, Y.Z., Huang, P. \& Plunkett, W. (1995) Functional compartmentation of dCTP pools. Preferential utilization of salvaged deoxycytidine for DNA repair in human lymphoblasts. J. Biol. Chem. 270, 631-637.

18. Hatzis, P., Al-Madhoon, A.S., Jullig, M., Petrakis, T.G., Eriksson, S. \& Talianidis, I. (1998) The intracellular localization of deoxycytidine kinase. J. Biol. Chem. 273, 30239-30243.

19. Sasvári-Székely, M., Spasokoukotskaja, T., Szőke, M., Csapó, Z., Turi A., Szántó, I., Eriksson, S. \& Staub, M. (1998) Activation of deoxycytidine kinase during inhibition of DNA synthesis by 2-chloro-2'-deoxyadenosine (Cladribine) in human lymphocytes. Biochem. Pharmacol. 56, 1175-1179.

20. Spasokoukotskaja, T., Sasvári-Székely, M., Keszler, G., Albertioni, F., Eriksson, S. \& Staub, M. (1999) 
Treatment of normal and malignant cells with nucleoside analogues and etoposide enhances deoxycytidine kinase activity. Eur. J. Cancer 35, 1862-1867.

21. Staub, M., Spasokoukotskaja, T., Taljanidisz, J., Sasvári-Székely, M. \& Antoni, F. (1983) Differences between lymphoid organs with respect to the phosphorylation of deoxycytidine and thymidine. Immunology Lett. 6, 137-142.

22. Sasvári-Székely, M., Spasokoukotskaja, T., Soóki-Tóth, Á., Pogány, G., Kopper, L. \& Staub, M. (1989). Deoxycytidine is salvaged not only into DNA but also into phospholipid precursors II. ara-C does not inhibit the later process in lymphoid cells. Biochem. Biophys. Res. Commun. 163, 1158-1167.
23. Szyfter, K., Sasvári-Székely, M., Spasokoukotskaja, T., Antoni, F. \& Staub, M. (1985) Purification and properties of deoxycytidine kinase. Acta Biochim. Biophys. Acad. Sci. Hung. 20, 173-182.

24. Heinemann, V. \& Plunkett, W. (1989) Modulation of deoxynucleotide metabolism by the deoxycytidylate deaminase inhibitor 3,4,5,6- tetrahydrodeoxyuridine. Biochem. Pharmacol. 38, 4115-4121.

25. Brautigan, D.L. \& Shriner, C.L. (1988) Methods to distinguish various types of protein phosphatase activity. Methods Enzymol. 159, 339-346.

26. Wang, L. M. \& Kucera, G.L. (1994) Deoxycytidine kinase is phosphorylated in vitro by protein kinase C $\alpha$. Biochim. Biophys. Acta 1224, 161-167. 